\title{
TREES AS SENTINELS OF METALLIC POLLUTION INDUCED BY MINING ALONG THE ODIEL RIVER (SOUTHERN IBERIAN PENINSULA)
}

\author{
ANNICK DELAPIERRE ${ }^{1,2,4}$, JUAN A. BALLESTEROS-CÁNOVAS ${ }^{1,2^{*} \text {, }}$ \\ JORGE BUZZI MARCOS ${ }^{3}$, VERA I. SLAVEYKOVA ${ }^{2,4}$, MARKUS STOFFEL ${ }^{1,2,4}$
}

\author{
${ }^{1}$ Department of Earth Sciences, University of Geneva, Switzerland. \\ ${ }^{2}$ Institute for Environmental Sciences, University of Geneva, Switzerland. \\ ${ }^{3}$ Department of Prospective Geoscientific, Spanish Geological Service, Spain.
}

${ }^{4}$ Department F.A. Forel for Environmental and Aquatic Sciences, University of Geneva, Switzerland.

\begin{abstract}
Mining activity is often responsible for the drainage of acid or metal-enriched waters to fluvial systems. The release of metals is especially disturbing due to the toxicity and persistence of these products and their accumulation in the biosphere. Hence, a systematic detection and delimitation of highly polluted floodplains and linkages between pollution and high-flow stages would likely assist the improvement of land management and ease the design of mitigation or rehabilitation measures. Here we test how trees growing in different geomorphic positions along a fluvial system uptake metal during floods and how these uptakes can be documented "a posteriori". To this end, we apply dendrogeochemical analyses to twenty Pinus pinaster Ait. trees growing on the banks of Odiel River (south-western Spain) as well as to five reference trees growing outside the river channel. In the field, trees were sampled with a large-diameter $(1 \mathrm{~cm})$ increment borer. In the lab, tree-ring series were dendrochronologically cross dated and separated into 5-yr blocks, so that wood blocks contained the dates of major floods. Then, Inductively Coupled Plasma Mass Spectrometry (ICPM) was employed to evaluate toxic metal concentrations in trees. Results point to clear correlations between the accumulation of toxic metals and the geomorphic position of trees within the fluvial network. We show that morphological units along a river exert control on toxic metal concentrations in trees, with uptake being much higher in trees located on meander cut banks than in trees growing on point-bar structures. Besides, we detect chemical signatures in trees located farthest away from the main river channel after the largest floods, but not in the aftermath of smaller events. We conclude that tree position is the single-most important determinant for metallic pollution in an environment controlled by fluvial processes, but also find that more studies are still needed to determine linkages with individual floods and interactions of metal uptake in roots via the water table in the river corridor.
\end{abstract}

\section{Árboles como indicadores de la contaminación metálica inducida por la minería a lo largo del río Odiel (sur de la Península Ibérica)}

RESUMEN. La actividad minera es responsable de vertidos de aguas enriquecidas con ácidos y metales. La liberación de metales es especialmente preocupante debido a su toxicidad y persistencia en los ecosistemas. La detección y delimitación sistemática de zonas contaminadas en la llanura de inundación puede contribuir a una mejor gestión de dichas zonas en relación con el ciclo hidrológico. En este trabajo se analiza si los árboles, que crecen en diferentes posiciones geomorfológicas, registran la absorción de metales durante eventos de inundaciones. Para ello, se aplicaron análisis dendroquímicos a veinticinco ejemplares de la especie Pinus pinaster Ait. que crecen en las orillas del río Odiel (suroeste de España). También se analizaron cinco árboles de referencia 
que crecen alejados del cauce del río. Los árboles fueron muestreados con una barrena de Pressler (diámetro $1 \mathrm{~cm}$ ) y las muestras fueron dendrocronológicamente fechadas, aislando bloques de 5 años que coincidían con eventos de inundaciones. Las concentraciones de metales tóxicos en muestras de árboles se midieron en dichos bloques mediante espectrometría de masas de plasma (ICPM). Los resultados revelan una clara correlación entre la acumulación de metales tóxicos y la ubicación geomorfológica de los árboles. La absorción de elementos metálicos fue mucho mayor en los árboles ubicados en el banco de orilla que en los árboles que crecen en las barras de sedimentos. Por otro lado, en los árboles más alejados del canal principal del río solo detectamos señales químicas después de las mayores inundaciones, pero no después de eventos más pequeños. Concluimos que la posición del árbol condiciona la señal dendroquímica asociada a procesos fluviales, aunque todavía se requieren más estudios para discernir los vínculos con eventos de inundaciones.

Key words: Tree ring, flood, fluvial geomorphology, dendrochemistry, heavy metal, pollution, Odiel River.

Palabras clave: Anillos de crecimiento, inundaciones, geomorfología fluvial, dendroquímica, elementos metálicos, contaminación, río Odiel.

Received: 15 June 2020

Accepted: 20 October 2020

* Corresponding author: J. A. Ballesteros-Canovas, Department of Earth Sciences, University of Geneva, Switzerland. E-mail: juan.ballesteros@unige.ch

\section{Introduction}

The incorporation of metallic pollutants in the hydrological cycle poses major environmental problems, with very direct impacts on living organism and human population worldwide (Foster et al., 1996; Ali et al., 2019). Anthropogenic activities, such as mining, have been hold responsible for the drainage of acid and metal-enriched waters, thereby contaminating river ecosystem downstream of their source as a result of the weathering of exposed minerals or tailing dam failures (Robles-Arenas et al., 2006; Rico et al., 2008). The release of metallic pollutants is particularly disturbing as they are typically highly toxic, persist, and as they have the capacity to accumulate in organisms and thus will ultimately end up in the food chain (Tchounwou et al., 2012). Even if multiple mining activities can be traced back easily into Roman times in the Old World (Hong et al., 1996; Nriagu et al., 1996; Ballesteros-Canovas et al., 2017), the recent industrialization has prompted a decentralized demand of metals for different purposes, with an unprecedented increase in legal and illegal mining activities worldwide (Banchirigah, 2008; Obeng et al., 2019).

In fluvial ecosystems, tracing metallic pollutants is essential for a proper management of sediments containing heavy metals and to limit harmful effects farther downstream in the river system (Hürkamp et al., 2009). One can reasonably anticipate that over the decades to come, mining activities will likely increase due to the ever-increasing demand of metals and rare earth elements. In addition, climate change has been demonstrated to enhance the hydrological cycle, which in turn could lead to more floods and again increase the spread of pollutants in river systems (Foulds et al., 2014). To adequately cope with these environmental issues of rising concern, it is essential to adopt adaption strategies at various levels: At the European level, the European Commission has issued two directives (2000/60/CE and 2006/11/CE) defining the obligation to evaluate and monitor the chemical status of water bodies in all member states. National governments have therefore put protocols in place through which water or sediment samples can be collected and analyzed ad hoc (Islam et al., 2015) with spectrophotometry, chromatography, or mass spectrometry (Fifield and Haines, 2000). These methods 
allow replicability and consistency of analyses over time, but they remain limited to the time period covered by sampling.

Long-term chemical records could instead contribute to a better identification of long-term trends in chemical concentrations and their linkages with environmental changes (Corella et al., 2017; Bing et al., 2016), but data does not readily exist so far. In this longer-term context, tree-ring series could become an interesting alternative as they can extend the time window covered by analysis farther back in time and thereby offer valuable insight into the temporal evolution of chemical compounds over decades to centuries (Cutter and Guyette, 1993). In addition to their longevity, the seasonal growth and dormancy of trees would also allow analysis with intra-annual resolution. Tree-ring series can also help in the creation of chronologies of environmental processes (Schweingruber, 2007), and thus assist determination of changes in chemical composition of soils and trees in the past (Smith and Shortle, 1996; Kabata and Pendias, 2001). Dendrochemistry deals with the analysis of trace elements in tree-ring series by assuming that a tree-ring represents the environmental chemistry of the year in which it was formed (Wright et al., 2014). As such, the discipline has lately evolved into a sub-branch of environmental forensic research (Balouet et al., 2009; Lageard et al., 2008; Stoffel et al., 2020) and now contributes to the understanding of physiological processes controlling uptake, transport and sequestration of chemical elements in the secondary xylem (Cutter and Guyette, 1993).

The potential of dendrochemistry in tracing historic pollution has gained in interest, primarily also in catchments where human-induced mining has led to contamination of rivers. Pioneering studies in the field go back to the 1970s when Sheppard and Funk (1975) found that Pinus ponderosa trees growing next to Spokane River (Idaho) can be employed to monitor changes in metal ion concentrations. More recently, Yanosky et al. (1995) analyzed chloride concentrations in Taxodium distichum growing on the Cape Fear River freshwater estuary to date the onset of saltwater intrusions induced by ongoing sea level rise. Saint-Laurent et al. (2010) analyzed tree-ring records from Fraxinus sp. growing along the Massawippi and Saint-François rivers (Quebec) contamination of trees with heavy metals released by industry. Likewise, tree rings have been used to record groundwater contamination with chlorinated solvents (Yanosky and Vroblesky, 1992; Balouet et al., 2009), but also to identify metal concentrations in water downstream of mines (Witte et al., 2004). The ability of tree rings to record pollution depends on the nature (or type) of pollutant and the exposure of a tree to the source of pollution (Cutter and Guyette, 1993, Rodríguez-Martin et al., 2018). Besides, some trace elements have been demonstrated to behave like microelements in such a way that they can translocate within the tree and across ring boundaries, therefore preventing dendrochemical analyses at annual resolution (Hagemeyer, 1993). Despite these possible limitations, the analysis of the chemical signatures in tree rings has the potential to improve our understanding of past pollution trends in fluvial ecosystems, even more so as trees are often ubiquitously present in fluvial corridors and have discernible tree rings, which also enables them to record fluvial processes and floods (Ballesteros-Canovas et al., 2015).

Here we test whether the accumulation of metallic pollutants in trees growing along a fluvial channel of the Odiel River is driven by their connectivity to the channel. We do so by analyzing trees growing at different positions with respect to the channel and that are affected by different magnitudes of floods. The study is based on the following premises: (i) temporal variations in metal concentrations in tree rings are in line with the historical development of mining activities upstream of the site where trees have been sampled; (ii) metals released into the river through acid drainage are absorbed by pine trees growing in the flood plain and contained in the rings of trees growing at locations where an interaction with the waters of Odiel River occurs; (iii) floods in a river impacted by mining drainage can be defined according to the concentrations of metals found in the tree rings (St. George et al., 2006). We assume that the application of dendrochemical analysis in trees affected by floods in the highly anthropogenic Odiel catchment will contribute to a better understanding of linkages between future floods and floodplain pollution. 


\section{Study site}

\subsection{Geomorphic description}

Odiel River is located in the Iberian Pyrite Belt (IPB), in the Province of Huelva, southwestern Spain (Fig. 1). The watershed has an area is $2333 \mathrm{~km}^{2}$ and the river flows on permeable bedrock over a distance of $140 \mathrm{~km}$ (Buzzi Marcos, 2012), i.e. between the Sierra de Aracena and the estuary of the Ría de Huelva (a UNESCO Biosphere Reserve, listed since 1983). The Odiel Basin contains three geological domains: in the uppermost part of the watershed, plutonic and metamorphic rocks (i.e. sericite schists, granites, gneiss, quartzites, marbles, and tuff) of the Upper Precambrian to Devonian can be found. In its middle part, bedrock is formed by volcanic and sedimentary rocks of the Iberian Pyrite Belt, locally known as the "PQ Group" (phyllite and quartzite group), the "Volcanic-Sedimentary Complex" (i.e. shales, greywackes, acid to basic volcanic and volcanoclastic rocks), and the "Culm Group" composed of flysch-like sequences of shales and greywackes belonging to the Upper Devonian to Middle Carboniferous. The lowest and southernmost portion of the basin is composed of siliciclastic materials of Miocene age (i.e. sands, silts, and clays) (Silva et al., 1990).

The volcanic-sedimentary complex holds enormous amounts of massive sulphides, forming one of the biggest polymetallic sulphide mining districts in the world (Leistel et al., 1998). These sulphides have been exploited for centuries, and more than a hundred mining sites can be found along Odiel River, corresponding to about 200 million $\mathrm{m}^{3}$ of sulphide-rich mine waste (Pérez López et al., 2011). Even if mining activities have ceased almost completely today, surficial weathering of pyrite-rich minerals still generates a continuous flow of acid mine drainage (AMD) into Odiel River. This drainage is responsible for low pH values and an increase of dissolved metal concentrations (Fig. 1B) (Borrego, 1992; Braungardt et al., 1998; Buzzi Marcos, 2012).

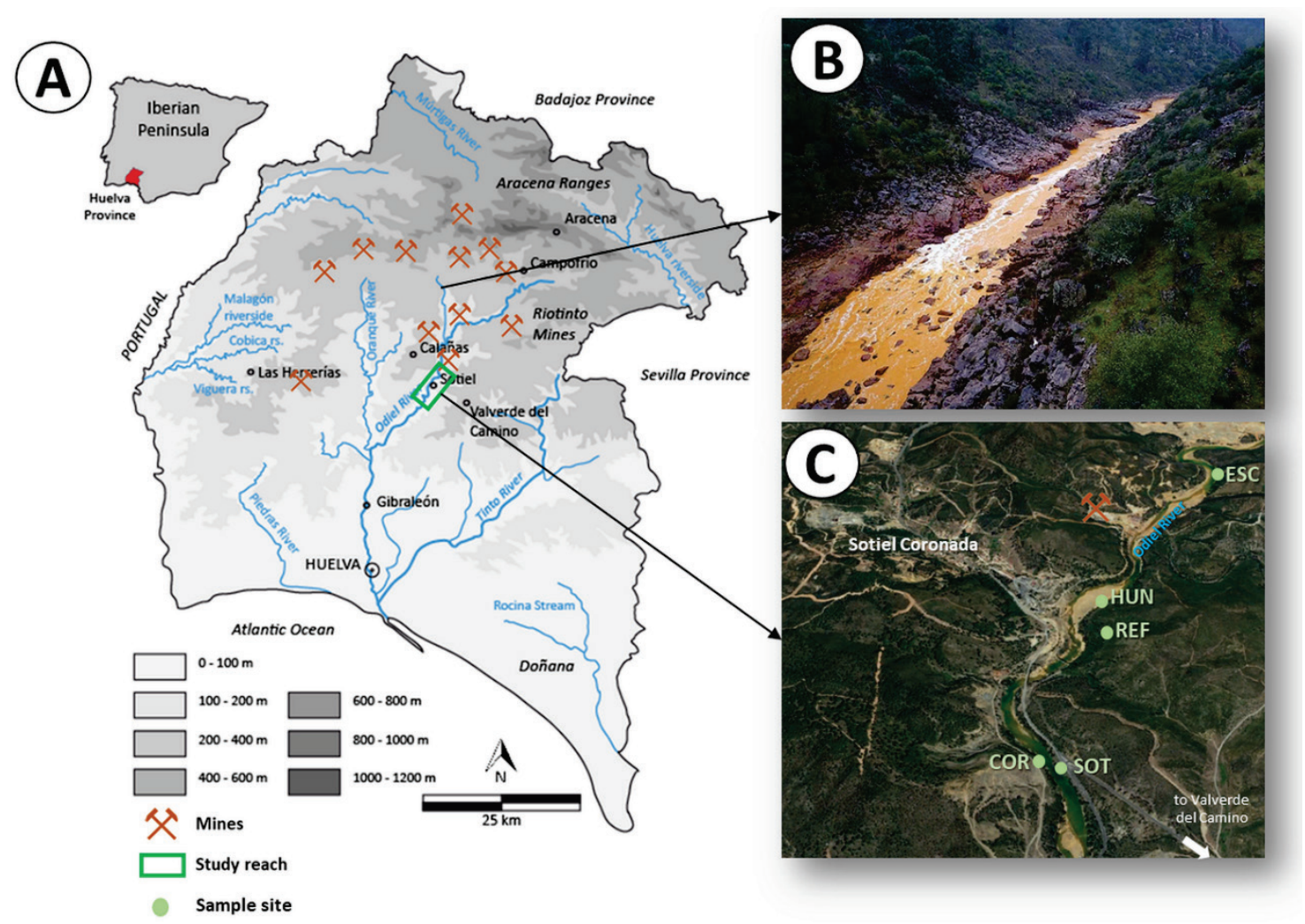

Figure 1. A) Location of the river reach analyzed along Odiel River. B) Metal-enriched waters in the Odiel River at Puente de los Cinco Ojos bridge. C) Localization of the five sampling sites along Odiel River (source: GoogleEarth). 
The Odiel River flows in a channel with a changing floodplain lithology and is characterized by low sinuosity but considerable lateral mobility, thereby favoring the development of sandbars along its course, as typical for bedload transport stream. The channel often diverts into different paths, forming braided side channels that are separated from each other by sandy and gravelly bars. The flow path is mostly linear, with smaller changes occurring where the Odiel River crosses rocks of differing competence. Flow is also controlled by walls from historic watermills, causing water diversion while favoring the retention of sediment. In its lower part, the Odiel River forms an estuary in which saltwater fluxes are controlled by tidal processes.

Climate in the study area is Mediterranean. Annual average precipitation is $617 \mathrm{~mm}$, whereas mean annual temperature is $18.5^{\circ} \mathrm{C}$, oscillating from below $0^{\circ} \mathrm{C}$ in winter to more than $40^{\circ} \mathrm{C}$ in summer. Vegetation is typical of Mediterranean sclerophyllous forests with several oak (Quercus suber, Q. ilex, Q. faginea) and conifer (Pinus pinaster and P. pinea) species accompanied by Mediterranean shrubs. In the Odiel catchments, allochthonous species are present as well, in particular eucalypts (Eucalyptus globulus and E. rostrata) (Cánovas, 2009). The riparian zone is characterized by acidophilic algae typical for mining environments (Euglena mutabilis and Klebsormidium sp., Grande et al., 2016).

River flow has been measured close to the estuary (1980-2011), at Gibraleón (lat: 37.3 N, long: $\left.-6.97^{\circ} \mathrm{W}\right)$, but the time series is highly fragmented with important data gaps. Highest discharge was typically observed in December and January, corresponding to the passage of Atlantic storms, whereas low runoff wass commonly found during dry summers. The rocky substrate of the Odiel catchment makes the river very reactive to any changes in precipitation: In January 1996 and December 2009, floods were triggered after intense rainfall over the study region, as reported by Morales et al. (2005) and Galván (2012); these events were also recorded partly by the gauge records. In the context of this study, we selected these two floods for the evaluation of their effects on metal concentrations in tree rings.

\subsection{Mining history in the Odiel catchment}

Archaeological evidence allows tracking back incipient mining activity for more than 4500 years (i.e. to the Copper Age; Grande et al., 2016). Since the Bronze Age and until the $6^{\text {th }}$ century BCE, Tartessians, Phoenicians, and Carthaginians exploited the mines in the Sierra de Aracena to extract lead, silver, and copper (Galván, 2012). Since the arrival of the Romans in the $3^{\text {rd }}$ century BCE, mining of copper, silver, and iron gained momentum as new technologies evolved, leaving several million tons of slag after the melting of minerals at the mining sites (Galván and Olías, 2015; Grande et al., 2016). Activity gradually slowed down thereafter to disappear completely during the $5^{\text {th }}$ century CE. During the Middle Ages, iron mining resumed in the area, especially during the Visigoths $\left(5^{\text {th }}\right.$ to $8^{\text {th }}$ centuries) and Arabic reigns ( $8^{\text {th }}$ to $15^{\text {th }}$ centuries). At the end of the $18^{\text {th }}$ century, mine exploitation gained again in importance as a result of relevant technological advances; it was fueled further by Industrial Revolution in the $19^{\text {th }}$ century (Grande et al., 2016). The demand for raw materials during this time was in fact important: copper was used for electrical industry, whereas sulphur was relevant to extract sulfuric acid used in chemical industry. Ever since, the revival of large-scale mining, supported by the appearance of the railway industry, triggered the export of raw materials from the IPB to most European countries (López et al., 2008; Grande et al., 2016). During the second half of the $20^{\text {th }}$ century, exploitation benefited from the reconstruction of infrastructure after the end of World War II. However, with the gradual but steady decline of copper prices on the market, environmental regulations of the European Union and the depletion of raw materials in various mines, activity slowed down again substantially and gradually disappeared from the area in the 1990s (Galván, 2012).

The mines remained abandoned for almost twenty years, but recently, international companies have explored possibilities to resume exploitation of certain historical mines in the IPB, and particularly in the Odiel Basin (Galván, 2012). These re-openings take place in a normative context that is quite 
different from that in place during the $20^{\text {th }}$ century, and companies are now subject to legal obligations and the realization of Environmental Impact Assessments, as prescribed by the National Environmental Assessment Act (Law 21/2013), in application of the European Directive 2014/52/EU.

\section{Material and methods}

\subsection{Sampling and tree-ring dating}

Tree-ring sampling along Odiel River was realized in early 2018 in the locality of Sotiel (Huelva, Spain). To test the influence of tree position on metal uptake, twenty trees were sampled at different positions within the river reach, i.e. at sites characterized by a straight channel and at sites characterized by meanders. Figure 2 provides insights into the sampling strategy and shows the sites that have been sampled: Trees from SOR $\left(37.58^{\circ},-6.84^{\circ}\right)$ and $\operatorname{COR}\left(37.59^{\circ},-6.84^{\circ}\right)$ grow in straight channel reaches, whereas those selected at $\operatorname{HUN}\left(37.59^{\circ},-6.84^{\circ}\right)$ and $\operatorname{ESC}\left(37.60^{\circ},-6.83^{\circ}\right)$ are located on point bars and cut banks, respectively, in a reach characterized by meanders.
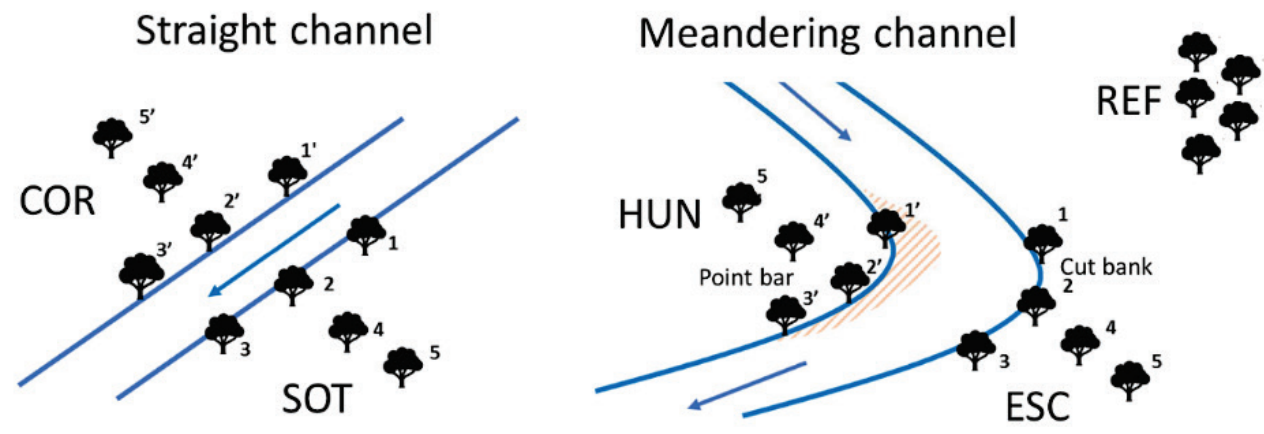

Figure 2. Trees sampled at different distances from the main course of the Odiel river at the four sites investigated: SOT, COR, HUN, and ESC. At the reference site (REF), tree selection was random.

In addition, we sampled five trees growing in the same area, but without any connection with the river, so as to use them as reference trees representing undisturbed growth (REF, $37.59^{\circ},-6.84^{\circ}$ ). Sampling was performed with increment borers of differing size. We used a 5-mm increment borer (i.e. inner diameter) to extract cores from the reference trees and to perform standard tree-ring dating. We also used a 10-mm increment borer to get increment cores for chemical analysis. To avoid contamination during sampling, the increment borers were cleaned with a metal-free oil before alcohol $\left(\right.$ at $\left.70^{\circ}\right)$ was used for further cleaning. Once the samples extracted, cores were stored plastic tubes filled with milliQ water and frozen at $-20^{\circ} \mathrm{C}$ until they were analyzed in the lab. In the field, additional information was recorded for each tree analyzed, such as tree diameter and its exact location (GPS).

In the lab, all samples were mounted on wooden supports, sanded with increasingly finer grit and then polished following standard dendrochronological procedures (Ballesteros-Canovas et al., 2015). Then, we carried out a visual reconnaissance and performed skeleton plots to evaluate the representativity of samples. Afterwards, tree-ring widths were measured with a Lintab ${ }^{\mathrm{TM}}$ measurement device connected to TSAP-Win software. We employed the cross-dating index (CDI) - a combination of the Gleichläufigkeit index (GLK) and Student's t-value test - to evaluate reliability of the cross dating between annual tree-ring chronologies (Rinn, 1996). 


\subsection{Sample preparation and analysis by inductively coupled plasma mass spectrometry (ICP-} $M S)$

The cores sampled with the 10-mm increment borer were prepared for chemical analysis and to quantify the evolution of metal uptake over time. To maximize the material available from each sample used for ICP-MS, we cut tree rings into blocks of 5 years: 1978-82, 1983-87, 1988-92, 1993-97, 19982002, 2003-07, 2008-12, and 2013-17. In addition, we assessed the impacts of floods by preparing 4year blocks prior and after the main floods in 1996 and 2009. Analysis of metal concentrations was adapted from Watmough and Hutchinson (2003): Samples were weighed after drying at $60^{\circ} \mathrm{C}$ for $72 \mathrm{~h}$, before they were calcined at $400^{\circ} \mathrm{C}$ for $6 \mathrm{~h}$. The resulting ashes were then weighed again and dissolved in $1 \mathrm{ml}$ of nitric acid supra-pure $\left(65 \% \mathrm{HNO}_{3}\right)$ for $24 \mathrm{~h}$. Ashes were then dissolved in $9 \mathrm{ml}$ of ultrapure water. Metal concentrations were analyzed by inductively coupled plasma mass spectrometry (ICP-MS, model 7700x, Agilent technologies, Morges, Switzerland) and multi-element calibration with certified standards (Certipur ICP multi-element standard VI Reference Material, Merck KGaA). Accuracy of the measurements was checked by BCR ${ }^{\circledR}-482$ Certified Reference Material (Lichen).

\subsection{Statistical analysis}

Results from the ICP-MS analyses were analyzed statistically using visual and descriptive approaches, including the analysis of linear trends and matrix correlation at $95 \%$ least significant difference (LSD), with the aim to identify linkages between metal uptake as a function of the vertical/horizontal distance of trees from the main channel of Odiel River. We also employed principal component analysis (PCA) to distinguish patterns associated with the analyzed sites. Finally, to determine whether metal uptake was statistically significant after the main floods events, we carried out non-parametric Wilcoxon tests (Sprent and Smeeton, 2001) at 95\% LSD.

\section{Results and discussion}

\subsection{Temporal evolution in the uptake of metallic pollutant in trees}

Average age of analyzed trees was $49 \pm 11$ years. The reference chronology and the trees sampled along the Odiel River cross-dated successfully with an average Gleichläufigkeit (GLK) of 65 and a cross-dating index (CDI) of 20. The PCA points to the presence of two main groups of elements present in samples that account for $58 \%$ of the variance (Fig. 3A): the first group (37.8\%) is formed by $\mathrm{Ag}, \mathrm{Cd}$, $\mathrm{Co}, \mathrm{Mn}$, and $\mathrm{Zn}$ whereas the second group (20.2\%) contains $\mathrm{Al}, \mathrm{Cu}, \mathrm{Cr}, \mathrm{Fe}, \mathrm{Mo}$, Ni and $\mathrm{V}$. In the first group, $\mathrm{Mn}, \mathrm{Cd}$ and Co are highly correlated and contribute significantly to the PCA, whereas the contribution of $\mathrm{Zn}$ and $\mathrm{Ag}$ is more limited. In the second group, Mo and Fe are overlapping, confirming a strong correlation between these two elements. $\mathrm{Cr}$, Ni and V show similar distributions, whereas the contribution of $\mathrm{Cu}$ is significantly lower if compared to other elements in the group. Interestingly, $\mathrm{Pb}$ does not contribute to any factor and appears isolated from the other elements, suggesting that its presence in trees is related to causes other than river contamination. The first group of elements is characterized by a centripetal pattern, with higher concentrations towards older rings, whereas the second group shows a centrifugal pattern, with higher concentrations towards the youngest rings (Fig. S.1). Fig. 3B shows the temporal evolution of average metal accumulation at each of the sites, including the reference site. Overall, $\mathrm{Al}, \mathrm{Ni}$, and $\mathrm{Cu}$ show the smallest changes over time at all sites and generally remain below the $25^{\text {th }}$ percentile (i.e. changes $<28 \%$ ). By contrast, $\mathrm{Zn}, \mathrm{Ag}$ or $\mathrm{Cd}$ show much larger changes over time, exceeding the $75^{\text {th }}$ percentile on average $(>42 \%)$.

Several environmental and physiological factors can explain the distribution patterns of metallic pollutants we observe in the analyzed trees. It is possible that the concentration of elements at the site is controlled by translocation processes between the sapwood and the heartwood (Meerts 2002; Scharnweber et al., 2016). Although analysis was constrained mostly to sapwood in our study, we 
observed an increase in the concentration of metals toward the limit between the sapwood and the heartwood (Fig. S.2), particularly for $\mathrm{Cr}, \mathrm{Mn}, \mathrm{Fe}, \mathrm{Ni}, \mathrm{Mo}, \mathrm{Ag}$, and $\mathrm{Pb}$, and to a lesser degree for $\mathrm{Al}, \mathrm{V}$, $\mathrm{Co}, \mathrm{Cu}, \mathrm{Zn}$, and $\mathrm{Cd}$ as well. Similar trends in metal concentration between the sap- and heartwood were described previously (Watmough and Hutchinson, 2002; Hagemeyer and Schäfer, 1995; Prohaska et al., 1998) and interpreted as a detoxification process induced by the storing of phytotoxic elements in dead heartwood cells (Donnelly et al., 1990). Likewise, correlations between elements could also be explained by physiological factors as $\mathrm{Fe}, \mathrm{Zn}$ and Mo as they are involved in different physiological processes (Nobel, 1999), In particular, Mo will depend on Fe for its assimilation, as well as on $\mathrm{Cr}$ and V (Hänsch and Mendel, 2009). Interestingly, Fe is generally considered as an element with low mobility in xylem (Prohaska et al., 1998), which would imply that the tendencies observed in trees would indeed depend on environmental factors, probably linked to the acidification of soils (Kabata and Pendias, 2001). Moreover, we find that $\mathrm{Zn}$ shows an irregular pattern, in agreement with observations made in previous studies focusing on Pinus strobus (Doucet, 2011), Acer pseudoplatanus (Watmough and Hutchinson, 1996) or Quercus robur (Hagemeyer, 1995). The fact that $\mathrm{Zn}$ is bioavailable to plants in its soluble form suggests that these variations could also be linked to the acid drainage of Odiel River. This assumption can be supported with results from the reference trees (REF) for which we could not find comparable variations in $\mathrm{Zn}$ or Co concentrations.

Results thus clearly evidence that mining activities upstream of the study sites are the main source of metallic pollution recorded in the analyzed trees. Therefore, and even if the most intense period of mine exploitation ceased in the 1990s, activity has resumed recently with a production of 4.6 million tons of $\mathrm{Co}$ and $\mathrm{Zn}$ annually. At the study site, metallic sulphide weathering occurs rapidly when these minerals are exposed to air, thereby releasing sulphates into running water bodies and lowering their $\mathrm{pH}$ values (Nordstrom and Alpers, 1999). As a consequence, the pyrite weathering products precipitate on the banks of the Odiel River in the form of complex sulphate crusts and efflorescence, and they change their composition during the meteorological year, following a well-known mineralogical evolution controlled by climatic and geomorphic factors (Buzzi Marcos, 2012). The mineral uptake that we identified in trees is in line with results from the chemical signature of sediments analyzed with spectroscopy (using hyperspectral sensors), and both processes are causally related to mine waste deposits. Analysis of hyperspectral time series can assist in the detection of changes in precipitated crusts and efflorescence along the flow path of Odiel River, thereby evidencing that the mine at Sotiel is indeed a notable source of acid mine drainage to the Odiel River (Buzzi Marcos, 2012; Buzzi et al., 2014; Riaza et al., 2017). 


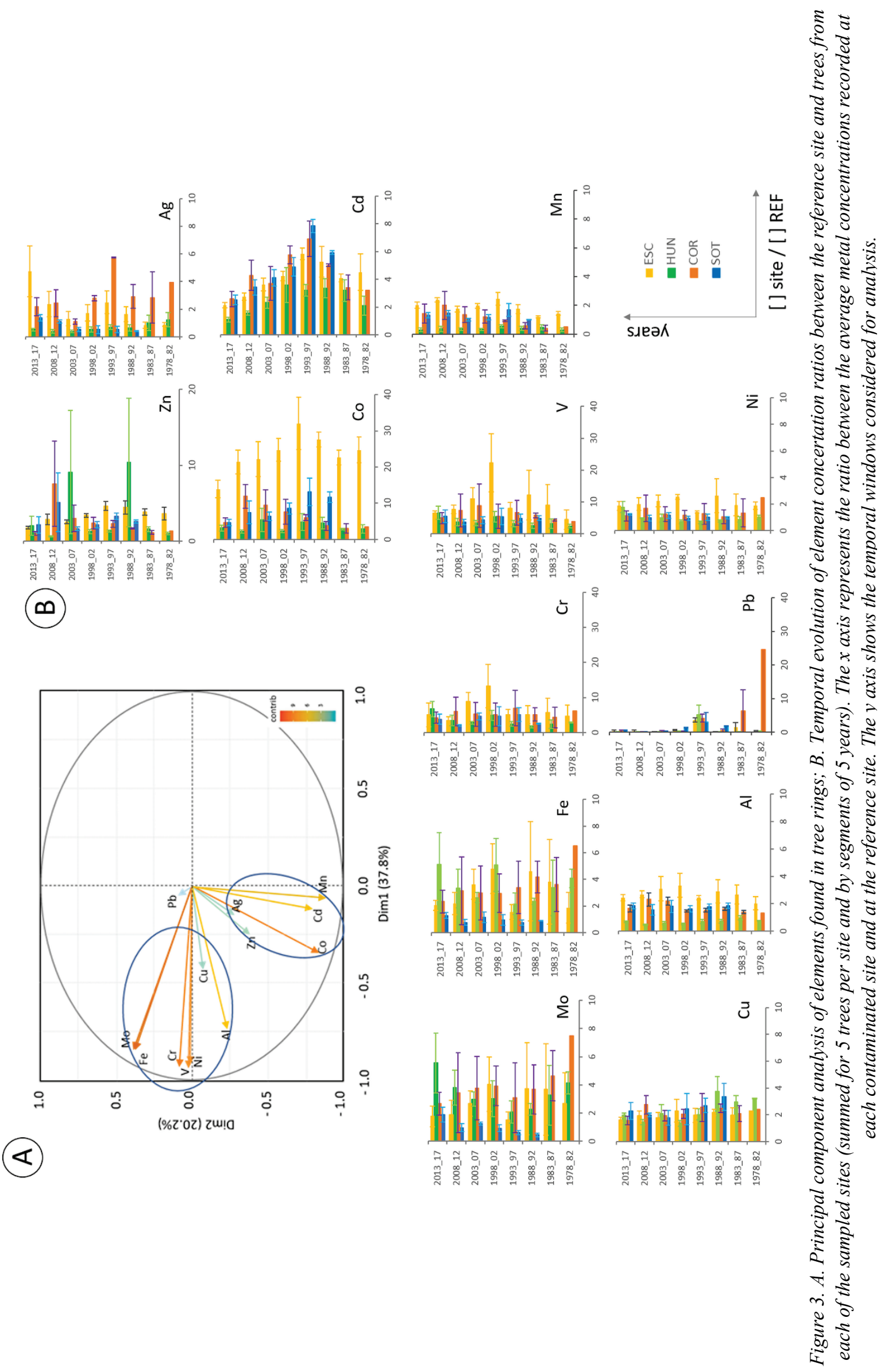




\subsection{Effect of the geomorphic position of trees on metal accumulation in trees}

Figure 4A shows significantly negative $(p<0.05)$ correlations between metal concentrations and the position of sampled trees, such as their distance to and height above the river channel: the greater the vertical and horizontal distances from the river, the lower the metal concentrations measured in the tree-ring series. The graph also shows that most elements are significantly positively correlated among each other, especially in the case of $\mathrm{Fe}, \mathrm{Cr}, \mathrm{V}, \mathrm{Ni}$, and $\mathrm{Mo}(\mathrm{r}>0.5)$. Mn is the exception to the rule and shows a negative correlation with $\mathrm{Fe}$ and $\mathrm{Mo}-$ as is $\mathrm{Pb}$ because it did not correlate with any other variable.
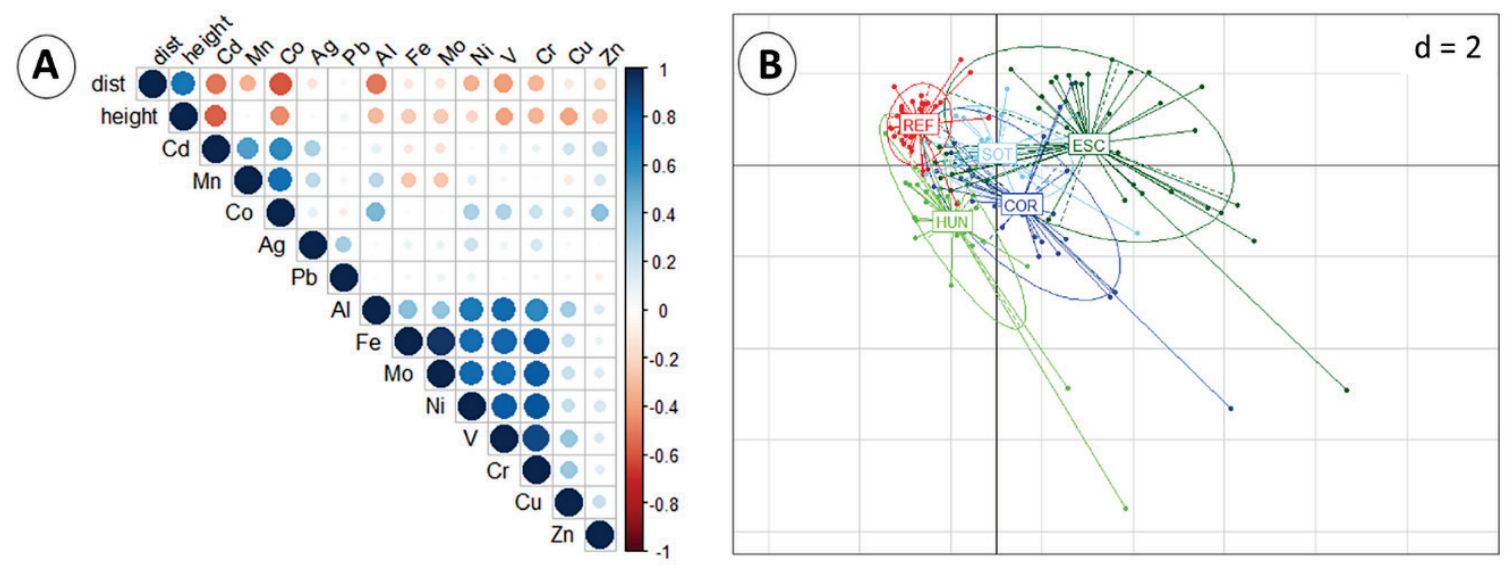

Figure 4. A) Correlations between metal concentrations in trees and the horizontal (dist) and vertical (height) distance of sampling sites from the channel. B) Principal Component Analysis of the element concentration measured in grouped trees at each sampling site.

Figure 4B illustrates results of the PCA with elements measured in trees classified by sampling site. By applying a Monte Carlo permutation test to this ordination, we show that $23.7 \%$ of the variability described by the PCA can be explained by fluvio-geomorphic differences between the sites ( $p$-value = 0.001). Overall, the highest metallic concentrations were found in trees growing on the cut banks of the meandering river reach (ESC). The distribution of concentrations was, by contrast, similar for trees growing in straight reaches (SOT and COR), whereas trees growing on the point bar of the meandering reach (HUN) showed lower concentrations. The reference site (REF), located on a nearby hillslope and thus without any connection to the channel network, showed the smallest metal concentrations.

The negative correlations between the horizontal and vertical distances of trees from the channel and metal concentration uptake support the initial assumption that the connectivity of trees to the fluvial system will control metal concentration uptake, resulting not only in lower, but also in more stable levels of metal concentrations in trees growing at REF. Results thus evidence a gradient of exposure of trees to metals transported by the river, and confirm findings of Madejón et al. (2004) stating that metal concentrations in Populus sp. growing in contaminated riparian zones of the Guadiamar River (southern Spain) were higher than in trees growing in unaffected neighboring areas. Moreover, our results are in line with observations of St. Laurent et al. (2009) by showing that the distance between analyzed trees and the channel plays a major role in contaminant assimilation.

In this study, we also provide insights into the effect of fluvio-geomorphic positions on metallic concentrations in trees: Whereas trees growing in straight channel reaches (i.e. sites COR and SOT) showed comparable metallic concentrations in their xylem, a clear difference was observed between the cut bank and point bar in the meandering reach, with higher metallic concentration found in those trees growing on the external side of the meander. This finding was unexpected insofar as sediments located on the inner side of a meander were generally thought to serve as reservoirs for metallic elements (e.g., 
Ciszewski, 2004; Ciszewski, 1998). On the other hand, the acidity of water (or at least its permanent proximity) may have played a key role favoring the release of metals from sediments to the water column, thereby increasing their solubility and mobility, which could then lead to enhanced bioavailability. Indeed, elements in acid rivers were shown to be present in a bioavailable ion form and could thus have been assimilated more easily by plants (Buzzi et al., 2014; Riaza et al., 2017). In addition, even if deposited sediments may contain significant quantities of metals (Morillo et al., 2002), the latter could form complexes with humic compounds or the clays contained in river sediments. If so, it would be possible that metal ions will be retained in a form that is not bioavailable to plants (Nobel, 1999).

\subsection{Effect of floods on metal accumulation in trees}

To analyze the effect of floods on metal uptake, blocks of five consecutive rings were prepared around the two major floods of 1996 and 2009. Sample COR4 was discarded due to fragmentation and the lack of sufficient wood material for analysis. Table 1 compares average metal concentrations observed in trees based on the Wilcoxon-test. We observe enhanced metal accumulation in trees located farther away from the channel (i.e. trees 4 and 5), especially after the flood of $2009(p<0.05)$. At the same time, data does not point to significant changes in the accumulation of metallic concentrations after the 1996 flood. Figure 5 therefore shows a dissimilar trend of element concentrations before and after floods with concentration of $\mathrm{Cu}, \mathrm{Zn}$ and $\mathrm{Pb}$ being lower (higher) after the 1996 (2009) floods. Although not significant, larger relative changes in metal concentration were observed for $\mathrm{Cr}, \mathrm{V}$, Mo and $\mathrm{Fe}\left(>75^{\text {th }}\right.$ percentile) after the 1996 flood, whereas lower concentration were observed for $\mathrm{Cu}, \mathrm{Zn}$, $\mathrm{Ag}, \mathrm{Pb}\left(<25^{\text {th }}\right.$ percentile $)$. By contrast, after the 2009 flood, larger relative changes in metal concentrations were measured for $\mathrm{Cu}, \mathrm{Zn}, \mathrm{Cr}, \mathrm{Pb}\left(>75^{\text {th }}\right.$ percentile), whereas lower concentrations were measured for $\mathrm{Ag}, \mathrm{Mn}$, and $\mathrm{Cd}\left(<25^{\text {th }}\right.$ percentile). These results imply a dissimilar response of trees to floods in terms of metal concentrations.

Table 1. Mean metallic concentrations before and after the 1996 and 2009 floods given as p-values obtained with Wilcoxon comparison tests (measured in 4-year blocks prior to and after the floods).

\begin{tabular}{llll}
\hline & $\mathbf{1 9 9 6}$ & Trees & p-value \\
\hline REF & All & 0.05759 \\
SOT, COR, HUN, ESC & $1-3$ & 0.4706 \\
SOT, COR, HUN, ESC & & $4-5$ & 0.2319 \\
\hline & $\mathbf{2 0 0 9}$ & Trees & p-value \\
\hline REF & All & 0.5206 \\
SOT, COR, HUN, ESC & $1-3$ & 0.7978 \\
SOT, COR, HUN, ESC & $4-5$ & 0.000668 \\
\hline
\end{tabular}




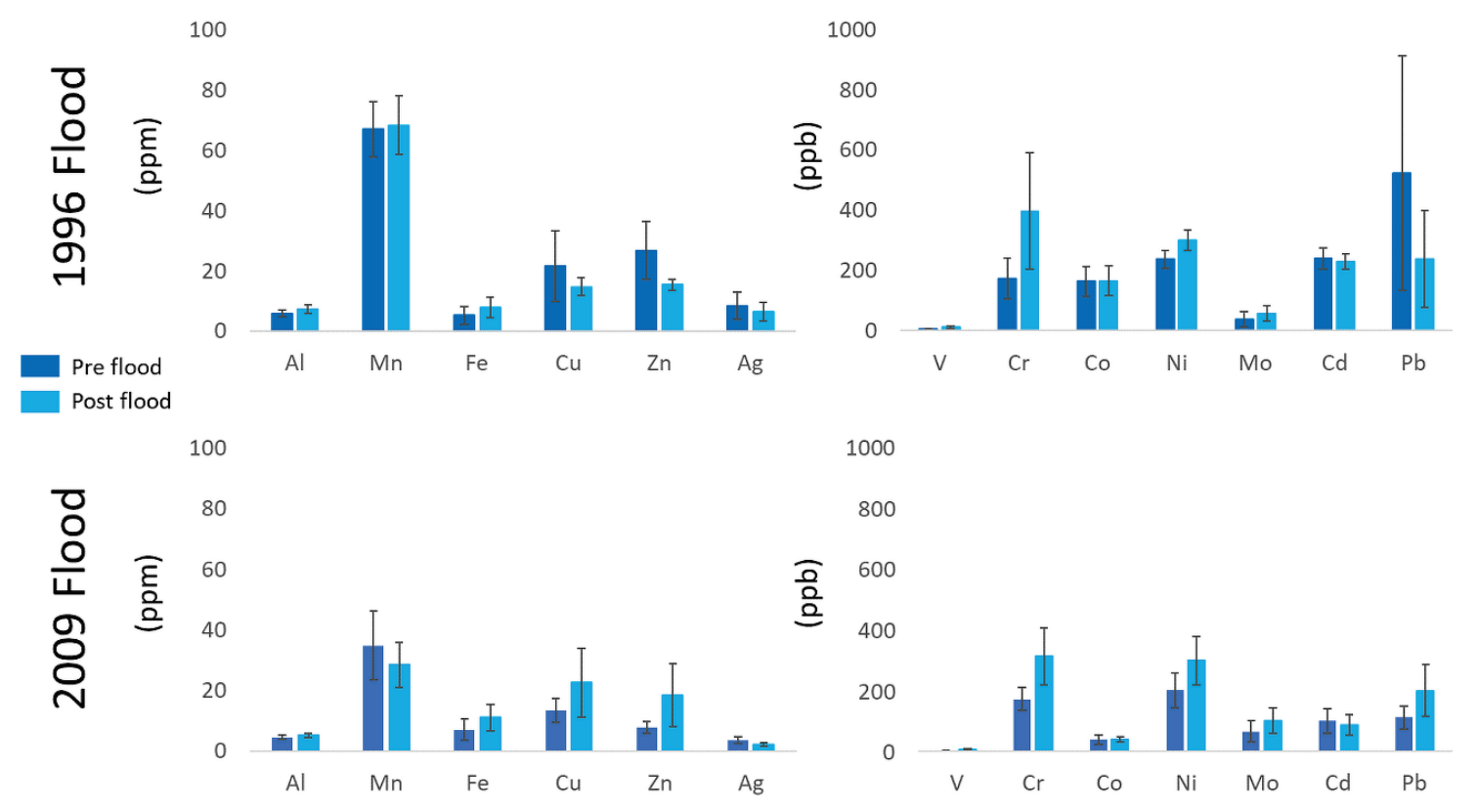

Figure 5. Response of element concentrations in trees after the major floods in the Odiel River in 1996 and 2009.

The assessment of rings in blocks of five before and after the events was realized with the idea to minimize translocation of elements through the xylem (Cheng et al., 2007), but also because a certain lag in the chemical response of trees to contamination has been described in the literature (Hagemeyer et al., 1992; Hagemeyer, 1995; Hagemeyer and Lohrie, 1995; Kabata and Pendias, 2001; Balouet et al., 2009). In the past, several studies analyzed chemical signatures based on aggregate measurements in consecutive tree rings so as to minimize the effects of translocation processes (Hagemeyer et al., 1992), as the latter are commonly considered to prevent interpretation at annual timescales (Guyette and Cutter, 1994).

The influence of floods on tree-ring records has been postulated by St. George et al. (2006) in his analysis of element concentrations in Quercus macrocarpa Michx. affected by persistent floods in the Red River (Canada). The authors did not find a clear and consistent chemical signature in the growthring records of trees that could be related to floods, but observed lower concentration of $\mathrm{Mg}, \mathrm{Mn}$ and $\mathrm{Sr}$ in trees after the largest $20^{\text {th }}$ century flood. More recently, St-Laurent et al. (2009) found anomalous concentrations of $\mathrm{As}, \mathrm{Cd}, \mathrm{Cu}, \mathrm{Ni}$, and $\mathrm{Zn}$ in riparian trees, and linked increased concentrations to floods along the Massawippi River (Canada), suggesting that floods were an important agent in transporting and depositing contaminants along the floodplains. In our study, we documented significant differences in element concentrations in those trees located far away from the channel after the 2009 flood but did not find comparable changes after the 1996 flood. Like St. George et al. (2006), we measured lower Mn concentrations in trees after the 2009 flood. Similar to St. Laurent et al. (2009), we found higher $\mathrm{Cu}, \mathrm{Ni}$, and $\mathrm{Zn}$ concentrations after the 2009 flood, but also realized that $\mathrm{Cd}$ showed invariant behavior. Interestingly, the response of $\mathrm{Zn}$ was not quite clear and even showed a completely opposite reaction after the 1996 flood. We explain these differences in response to the 1996 and 2009 floods by differences in flood magnitude, as discharge during the 1996 flood $\left(111.84 \mathrm{~m}^{3} / \mathrm{s}\right)$ corresponds to only c. $60 \%$ of that recorded during the 2009 flood $\left(186.10 \mathrm{~m}^{3} / \mathrm{s}\right)$. We argue that changes in metal concentrations after the 2009 flood can be explained by (i) the much larger connectivity between the main channel and those trees that are normally located far away from the river course and (ii) the mobilization of sediments transported by the flood to portions of the river corridor that are only activated by major events (St. Laurent et al., 2009). This assumption is supported further by the fact that trees at the REF site did not 
exhibit any changes after the two floods. In our case, the low Mn concentration found in trees after the two floods cannot be explained as a secondary process in wood formation during anoxic conditions as found as a result of the permanent flooding of riparian vegetation over several weeks (St. George et al., 2006), because, unlike Red River (Canada), the Odiel River is characterized by a quick hydrological response (Aguirre et al., 2003) and short-lived, almost flashy, flood episodes.

Nonetheless, we cannot rule out the possibility that floods could also have an opposite effect on metal concentrations in tree rings. Floods could in fact mobilize and transport metallic elements and thereby affect trees located far away from the main channel, but also dilute metallic elements contained in soil by the simple supply of excessive precipitation and surface runoff as often observed in Mediterranean climates during floods. This mechanism could be particularly relevant for floods in autumn when the flush can mobilize efflorescences of soluble salts that have been deposited on the banks of Odiel River during the low water stages of the summer months. Besides, long-lasting rainfall events could saturate soils in the catchment and modify its $\mathrm{pH}$ (Norton, 1977; Riaza et al., 2012); these persistent rainfall events are indeed a typical cause of floods in the Atlantic basin (Benito et al., 1996; Ballesteros-Cánovas et al., 2018). On the other hand, changes in soil $\mathrm{pH}$ may affect the bioavailability of metallic pollutants and their uptake by trees (Augustin et al., 2005). This latter effect could be even more relevant in the current context of soil acidification in the study area, as illustrated by the Mn/Al ratio found in the xylem of the trees analyzed (Fig. S.3).

\section{Conclusions}

Anthropogenic activities result in an incorporation of metallic pollutants in the hydrological cycle, posing major environmental problems. In this study, we analyzed twenty-five $P$. pinaster trees growing along Odiel River, a Mediterranean stream that is highly affected by mining activities. Results of the dendrochemical analysis of trees growing in the river corridor were compared with reference trees growing at a site that has not been affected by floods. We hypothesized that $P$. pinaster trees show a chemical signature that is controlled by the magnitude of floods and the fluvio-geomorphic position of trees within the river corridor. We conclude that the fluvial position of trees and their horizontal and vertical distance from the river channel determine metal accumulations found in trees. We observe that trees located farther away from the fluvial channel show a significant response to the 2009 flood, but trees lack a clear signal after the 1996 flood, presumably as a result of the much smaller magnitude of the 1996 flood. Despite certain limitations, we also conclude that trees are valuable sentinels for toxic metals and herewith call for follow-up research to test such linkages, with the aim to determine metal uptake by trees in a way that it could soon support land management strategies in fluvial ecosystem affected by mining in various contexts worldwide.

\section{Acknowledgements}

This study has been partly funded by the Foundation Ernst et Lucie Schmidheiny. Warm thanks are extended to Isabelle Worms for performing the ICPMS measurements, to Asuncion Riaza for initial discussion as well as to the anonymous external reviewers.

\section{References}

Aguirre, J.A.M., Sánchez, J.C.R., Arce, P.J. S. 2003. Avenidas torrenciales en el Arroyo del Partido y su incidencia en la Marisma del Parque Nacional de Doñana. Organismo Autónomo Parques Nacionales, Madrid.

Ali, H., Khan, E. Ilahi, I. 2019. Environmental Chemistry and Ecotoxicology of Hazardous Heavy Metals: Environmental Persistence, Toxicity, and Bioaccumulation. Journal of Chemical, 6730305. https://doi.org/10.1155/2019/6730305 
Alpers, C.N., Nordstrom, D.K., Spitzley, J. 2003. Extreme acid mine drainage from a pyritic massive sulfide deposit: The Iron Mountain endmember. In: J.L. Jambor, D.W. Blowes, A.I.M. Ritchie (Eds.). Environmental Aspects of Mine-Wastes. Mineralogical Association of Canada, pp. 407-430.

Augustin, S., Stephanowitz, H., Wolff, B., Schröder, J., Hoffmann, E. 2005. Manganese in Tree Rings of Norway Spruce as an Indicator for Soil Chemical Changes in the Past. European Journal of Forest Research 124 (4), 313-318. https://doi.org/10.1007/s10342-005-0084-4

Ballesteros-Cánovas, J.A., Stoffel, M., St George, S., Hirschboeck, K. 2015. A review of flood records from tree rings. Progress in Physical Geography 39 (6) 794-816. https://doi.org/10.1177/0309133315608758

Ballesteros-Cánovas, J.A., Stoffel, M., Benito, G., Rohrer, M., Barriopedro, D., García-Herrera, R., Beniston, M., Brönnimann, S. 2018. On the extraordinary winter flood episode over the North Atlantic Basin in 1936. Annals of the New York Academy of Sciences 1436, 206-216. https://doi.org/10.1111/nyas.13911

Ballesteros-Cánovas, J.A., Stoffel, M., Martín-Duque, J.F., Corona, C., Lucía, A., Bodoque, J.M., Montgomery, D.R. 2017. Gully evolution and geomorphic adjustments of badlands to reforestation. Scientific Reports 7,45027 .

Balouet, J.C., Smith, K.T., Vroblesky, D., Oudijk, G. 2009. Use of dendrochronology and dendrochemistry in environmental forensics: does it meet the Daubert criteria? Environmental Forensics 10 (4), 268-276. https://doi.org/10.1080/ 15275920903347545

Banchirigah, S.M. 2008. Challenges with eradicating illegal mining in Ghana: A perspective from the grassroots. Resources Policy 33(1), 29-38. https://doi.org/10.1016/ j.resourpol.2007.11.001

Benito, G., Machado, M.J., Pérez-González, A. 1996. Climate change and flood sensitivity in Spain. Geological Society, London, Special Publications, 115(1), 85-98. https://doi.org/10.1144/GSL.SP.1996.115.01.08

Bing, H., Wu, Y., Zhou, J., Li, R., Wang, J. 2016. Historical trends of anthropogenic metals in Eastern Tibetan Plateau as reconstructed from alpine lake sediments over the last century. Chemosphere 148, 211-219. https://doi.org/10.1016/j.chemosphere.2016.01.042

Borrego, J. 1992. Sedimentología del estuario del Río Odiel, Huelva, S.O. España. PhD thesis, Univ. of Sevilla, Sevilla, Spain.

Braungardt, C.B., Achterberg, E.P., Mimmo, M. 1998. Behaviour of disolved trace metals in the Rio Tinto/Rio Odiel Esturine System. In: J.A. Morales, J. Borrego, J. (Eds). European land-ocean interaction studies. Second annual scientific conference. Abstract 51.

Buzzi Marcos, J. 2012. Imaging Spectroscopy to Evaluate the Contamination from Sulphide Mine Waste in the Iberian Pyrite Belt Using Hyperspectral Sensors (Huelva, Spain). Ph.D. Thesis, Universidad de León, León, Spain.

Buzzi, J., Riaza, A., García-Meléndez, E., Weide, S., Bachmann. M. 2014. Mapping Changes in a Recovering Mine Site with Hyperspectral Airborne Hymap Imagery (Sotiel, SW Spain). Minerals 4, 313-329. https://doi.org/10.3390/min4020313

Cánovas, C.R. 2009. La calidad del agua de los ríos Tinto y Odiel: evolución temporal y factores condicionantes de la movilidad de los metales. Universidad de Huelva. Huelva.

Cheng, Z., Buckley, B.M., Katz, B., Wright, W., Bailey, R., Smith, K.T., van Geen, A. 2007. Arsenic in tree rings at a highly contaminated site. Science of the Total Environment 376 (1-3), 324-334. https://doi.org/10.1016/j.scitotenv.2007.01.074

Ciszewski, D. 1998. Channel processes as a factor controlling accumulation of heavy metals in river bottom sediments: consequences for pollution monitoring (Upper Silesia, Poland). Environmental Geology 36 (1), 45-54. https://doi.org/10.1007/s002540050319

Ciszewski. D. 2004. Pollution of Mala Panew river sediments by heavy metals: Part I. Effect of changes in river bed morphology. Polish Journal of Environmental Studies 13 (6), 589-595.

Consejería de Agricultura, Pesca y Medio Ambiente (Junta de Andalucía), 2014. Anejo 5 Implantación del régimen de caudales ecológicos. Demarcación Hidrográfica del Tinto, Odiel y Piedras. Memoria del Ciclo de Plan Hidrológico de la Planificación Hidrológica 2015/2021. 
Corella, J.P., Valero-Garcés, B.L., Wang, F., Martínez-Cortizas, A., Cuevas, C.A., Saiz-Lopez, A. 2017. 700 years reconstruction of mercury and lead atmospheric deposition in the Pyrenees (NE Spain). Atmospheric Environment 155, 97-107. https://doi.org/10.1016/j.atmosenv.2017.02.018

Cutter, B.E., Guyette. R.P. 1993. Anatomical, Chemical, and Ecological Factors Affecting Tree Species Choice in Dendrochemistry Studies. Journal of Environment Quality 22 (3), 611-619. https://doi.org/10.2134/jeq1993.00472425002200030028x

Donnelly, J.R., Shane, J.B., Schaberg P.G. 1990. Lead mobility within the xylem of red spruce seedlings: implications for the development of pollution histories. Journal of Environmental Quality 19, 268-271. https://doi.org/10.2134/jeq1990.00472425001900020012x

Doucet, A. 2011. Perspective spatio-temporelle et impacts des contaminants atmosphériques d'origine diffuse sur les forêts périurbaines du sud-est du Canada : une approche dendrogéochimique. Université du Québec, Quebec, Canada.

Fifield, F.W., Haines, P.J. (Eds.). 2000. Environmental analytical chemistry. Wiley.

Foster, I.D.L., Charlesworth, S.M. 1996. Heavy metals in the hydrological cycle: trends and explanation. Hydrological Processes $10 \quad$ (2), 227-261. https://doi.org/10.1002/(SICI)10991085(199602)10:2<227::AID-HYP357>3.0.CO;2-X

Foulds, S.A., Brewer, P.A., Macklin, M.G., Haresign, W., Betson, R.E., Rassner, S.M.E., 2014. Flood-related contamination in catchments affected by historical metal mining: an unexpected and emerging hazard of climate change. Science of the Total Environment 476, 165-180. https://doi.org/10.1016/j.scitotenv.2013.12.079

Galván González, L. 2012. Modelización hidrológica del rio Odiel: aplicación al estudio de la contaminación por drenaje ácido de minas. Ph.D. Thesis, Universidad de Huelva, Huelva, Spain.

Galván, L., Olías, M., 2015. Estudio de la contaminación por drenaje ácido de minas en la cuenca del Río Odiel. Boletín de la Sociedad Española de Mineralogía 20, 51-52.

George, S.S., Outridge, P.M., Nielsen, E. 2006. High-resolution dendrochemical analysis of flood-affected oaks using laser ablation ICP-mass spectrometry. IAWA Journal 27(1), 19-31. https://doi.org/10.1163/22941932-90000134

Grande, J.A., Pérez Ostalé, E., de la Torre Sánchez, M.L., Fernandes Valente, T.M., Borrego Flores, J., Pérez Macias, J.A., Santisteban Fernández, M., Garrido Morillo, R., Romero Macías, E., Salmerón García, I. 2016. Drenaje ácido de mina en la Faja Pirítica Ibérica: Técnicas de estudio e inventario de explotaciones. Servicio de Publicaciones Universidad de Huelva, Huelva, Spain.

Gross, J.H. 2006. Mass spectrometry: a textbook. Springer, 1-518 pp., Heilderberg,

Guyette, R.P., Cutter. B.E. 1994. Barium and manganese trends un tree-rings as monitors of sulfur deposition. Water, Air, and Soil Pollution 73, 213-223. https://doi.org/10.1007/BF00477987

Hagemeyer, J. 1995. Radial distributions of Cd in stems of oak trees (Quercus robur L.) re-analyzed after 10 years. Trees-Structure and Function 9 (4): 200-203. https://doi.org/10.1007/BF00195273

Hänsch, R., Mendel, R. R. 2009. Physiological Functions of Mineral Micronutrients (Cu, Zn, Mn, Fe, Ni, Mo, B, Cl). Current Opinion in Plant Biology 12 (3): 259-266. https://doi.org/10.1016/j.pbi.2009.05.006

Hong, S., Candelone, J.P., Patterson, C.C., Boutron, C.F. 1996. History of ancient copper smelting pollution during Roman and medieval times recorded in Greenland ice. Science 272(5259), 246-249. https://doi.org/10.1126/science.272.5259.246

Hürkamp, K., Raab, T., Völkel, J. 2009. Lead pollution of floodplain soils in a historic mining area-age, distribution and binding forms. Water, air, and soil pollution 201(1-4), 331-345. https://doi.org/10.1007/s11270-008-9948-9

Islam, M.S., Ahmed, M.K., Raknuzzaman, M., Habibullah-Al-Mamun, M., Islam, M.K. 2015. Heavy metal pollution in surface water and sediment: a preliminary assessment of an urban river in a developing country. Ecological Indicators 48, 282-291. https://doi.org/10.1016/j.ecolind.2014.08.016 
Kabata-Pendias, A., Pendias, H. 2001. Trace elements in soils and plants. 3rd ed. FI CRC Press, 1-413 pp., Boca Raton, US.

Lageard, J.G.A., Howell, J.A., Rothwell, J.J., Drew, I.B. 2008. The utility of Pinus sylvestris L. in dendrochemical investigations: Pollution impact of lead mining and smelting in Darley Dale, Derbyshire, UK. Environmental Pollution 153 (2), 284-294. https://doi.org/10.1016/j.envpol.2007.08.031

Leistel, J.M., Marcoux, E., Thiéblemont, D., Quesada, C., Sánchez, A., Almodóvar, G.R., Sáez, R.J.M.D. 1997. The volcanic-hosted massive sulphide deposits of the Iberian Pyrite Belt Review and preface to the Thematic Issue. Mineralium Deposita 33 (1-2), 2-30.

Lewis, T.E. (Ed.). 1995. Dendrochronology and dendrochemistry in regional ecosystem health assessments: the forest health monitoring experience. In: Tree Rings as Indicators of Ecosystem Health, 25 June 1993, Penn State University, University Park, Pa. CRC Press, Boca Raton, Fla. pp. 1-16.

López, E., Sánchez, J., Diez, M., Santofimia, E., Reyes J., 2008. Cortas mineras inundadas de la Faja Piritica: inventario e hidroquímica. Instituto Geológico y Minero de España. Madrid.

Madejon, P., Marañón, T., Murillo, J. M., Robinson, B. 2004. White poplar (Populus alba) as a biomonitor of trace elements in contaminated riparian forests. Environmental Pollution 132 (1), 145-155. https://doi.org/10.1016/j.envpol.2004.03.015

Meerts, P. 2002. Mineral nutrient concentrations in sapwood and heartwood: a literature review. Annals of Forest Science 59 (7), 713-722. https://doi.org/10.1051/forest:2002059

Morales, J.A., Pons, J.M., Cantano, M. 2005. Introducción al análisis de los riesgos de inundación en las riberas de las áreas estuarinas: El caso de las poblaciones adyacentes a la Ría de Huelva (SO España). Geogaceta 37, 243-246.

Morillo, J., Usero, J., Gracia, I. 2002. Partitioning of metals in sediments from the Odiel River (Spain). Environment International 28 (4), 263-271. https://doi.org/10.1016/S0160-4120(02)00033-8

Nobel, P.S. 1999. Physicochemical and environmental plant physiology. Academic Press, San Diego, California, USA.

Nordstrom, D.K., Alpers, C.N. 1999. Geochemistry of acid mine waters. In: The environmental geochemistry of mineral deposits, 6A: 133-160. Rev Econ Geol. Plumlee GS, Logsdon MJ.

Norton, S.A. 1977. Changes in chemical processes in soils caused by acid precipitation. Water, Air, and Soil Pollution, 7(3), 389-400. https://doi.org/10.1007/BF00284133

Nriagu, J.O. 1996. A history of global metal pollution. Science 272 (5259), 223-223. https://doi.org/10.1126/science.272.5259.223

Obeng, E.A., Oduro, K.A., Obiri, B.D., Abukari, H., Guuroh, R.T., Djagbletey, G.D., Appiah, M., 2019. Impact of illegal mining activities on forest ecosystem services: local communities' attitudes and willingness to participate in restoration activities in Ghana. Heliyon 5 (10), e02617. https://doi.org/10.1016/j.heliyon.2019.e02617

Pérez-López, R., Nieto, J.M., López-Cascajosa, M.J., Díaz-Blanco, M.J., Sarmiento, A.M., Oliveira, V., SánchezRodas, D. 2011. Evaluation of heavy metals and arsenic speciation discharged by the industrial activity on the Tinto-Odiel estuary, SW Spain. Marine Pollution Bulletin 62, 405-411. https://doi.org/10.1016/j.marpolbul.2010.12.013

Riaza, A., Buzzi, J., García-Meléndez, E., Carrère, V., Sarmiento A., Müller, A. 2012. River acid mine drainage: sediment and water mapping through hyperspectral Hymap data. International Journal of Remote Sensing 33 (19), 6163-6185. https://doi.org/10.1080/01431161.2012.675454

Riaza, A., Buzzi, J., García-Meléndez, E., Del Moral, B., Carrère, V., Richter, R. 2017. Monitoring salt crusts on an AMD contaminated coastal wetland using hyperspectral Hyperion data (Estuary of the River Odiel, SW Spain). International Journal of Remote Sensing 38 (12), 3735-3762. https://doi.org/10.1080/01431161.2017.1302621

Rico, M., Benito, G., Diez-Herrero, A. 2008. Floods from tailings dam failures. Journal of Hazardous Materials 154 (1-3), 79-87. https://doi.org/10.1016/j.jhazmat.2007.09.110. 
Rinn F. 1996. Tsap V. 3.6 Reference Manual: Computer Program for Tree-Ring Analysis and Presentation, 263 pp., Heidelberg, Germany,

Robles-Arenas, V.M., Rodríguez, R., García, C., Manteca, J.I., Candela, L. 2006. Sulphide-mining impacts in the physical environment: Sierra de Cartagena-La Unión (SE Spain) case study. Environmental Geology 51(1), 47-64. https://doi.org/0.1007/s00254-006-0303-4

Rodríguez-Martín, J.A.R., Gutiérrez, C., Torrijos, M., Nanos, N. 2018. Wood and bark of Pinus halepensis as archives of heavy metal pollution in the Mediterranean Region. Environmental Pollution 239, 438-447. https://doi.org/10.1016/ j.envpol.2018.04.036

Prohaska, T., Stadlbauer, C., Wimmer, R. Stingeder, G., Latkoczy, Ch., Hoffmann, E., Stephanowitz, H. 1998. Investigation of element variability in tree rings of young Norway spruce by laser-ablation-ICPMS. Science of the Total Environment 219 (1): 29-39. https://doi.org/10.1016/S0048-9697(98)00224-1

Saint-Laurent, D., St-Laurent, J., Duplessis, P., Lavoie, L. 2010. Isotopic record of lead contamination in alluvial soils and tree rings on recent floodplains (Southern Québec, Canada). Water, Air, \& Soil Pollution 20, 9(1-4), 451-466. https://doi.org/10.1007/s11270-009-0213-7

Scharnweber, T., Hevia, A., Buras, A., van der Maaten, E., Wilmking, M. 2016. Common trends in elements? Within-and between-tree variations of wood-chemistry measured by X-ray fluorescence-A dendrochemical study. Science of the Total Environment 566, 1245-1253. https://doi.org/10.1016/j.scitotenv.2016.05.182

Schweingruber, F.H., 2007. Wood structure and environment. Springer, Heidelberg, Germany.

Sheppard, J.C., Funk. W.H. 1975. Trees as environmental sensors monitoring long-term heavy metal contamination of Spokane River, Idaho. Environmental Science \& Technology 9 (7), 638-642.

Silva, J.B., Oliveira, J.T., Ribeiro, A. 1990. Structural outline. In: R.D. Dallmeyer, E.M. García (Eds.). PreMesozoic Geology of Iberia. IGCP-Project 233 (Terranes in the Circum-Atlantic Palezoic Orogens), Springer, pp. 348-362, Berlin, Heidelberg. https://doi.org/10.1007/978-3-642-83980-1_24

Smith, K.T., Shortle, W.C. 1996. Tree biology and dendrochemistry. In: J.S. Dean, D.M. Meko, T.W. Swetnam (Eds.). Tree rings, Environment and Humanity. Proceedings of an International Conference. Tucson, AZ: Radiocarbon: 629-635.

Sprent, P., Smeeton, N.C. 2001. Applied Nonparametric Statistical Methods. 3rd Edition, Chapman \& Hall/CRC, 463 pp., Boca Raton, US.

St. George, S., Outridge, P.M., Nielsen, E. 2006. High-resolution dendrochemical analysis of flood-affected oaks using laser ablation ICP-mass spectrometry. IAWA journal 27(1), 19-31.

St. Laurent, J., Saint-Laurent, D., Duplessis, P., Hähni, M., Begin, C. 2009. Application of dendrochronological and dendrochemical methods for dating contamination events of the Saint-François and Massawippi riverbanks (Québec, Canada). Soil, Sediment and Contamination 18 (5), 642-668. https://doi.org/10.1080/15320380903113626

Stoffel, M., Slaveykova, V.I., Corona, C., Ballesteros-Cánovas, J.A. 2020. When scientists become detectives: investigating systematic tree poisoning in a protected cove. Heliyon 6(2), e03386. https://doi.org/10.1016/j.heliyon.2020.e03386

Tchounwou, P.B., Yedjou, C.G., Patlolla, A.K., Sutton, D.J. 2012. Heavy metal toxicity and the environment. In: A. Luch (Ed.). Molecular, Clinical and Environmental Toxicology. Springer, pp. 133-164, Basel.

Watmough, S.A., Hutchinson, T.C. 1996. Analysis of Tree Rings Using Inductively Coupled Plasma Mass Spectrometry to Record Fluctuations in a Metal Pollution Episode. Environmental Pollution 93 (1), 93 102. https://doi.org/10.1016/0269-7491(95)00107-7

Watmough, S.A., Hutchinson, T.C. 2002. Historical changes in lead concentrations in tree-rings of sycamore, oak and Scots pine in north-west England. Science of the Total Environment 293 (1): 85-96. https://doi.org/10.1016/S0048-9697(01)01149-4 
Watmough, S.A., Hutchinson, T.C. 2003. A comparison of temporal patterns in trace metal concentration in tree rings of four common European tree species adjacent to a $\mathrm{Cu}-\mathrm{Cd}$ refinery. Water, Air, \& Soil Pollution 146 (1): 225-241. https://doi.org/10.1023 /A:1023952417583

Witte, K.M., Wanty, R.B., Ridley, W.I. 2004. Engelmann Spruce (Picea engelmannii) as a biological monitor of changes in soil metal loading related to past mining activity. Applied Geochemistry 19 (9), 1367-1376. https://doi.org/10.1016/j.apgeochem.2004.01.022

Wright, G., Woodward, C., Peri, L., Weisberg, P.J., Gustin, M.S. 2014. Application of tree rings [dendrochemistry] for detecting historical trends in air $\mathrm{Hg}$ concentrations across multiple scales. Biogeochemistry 120 (1-3), 149-162. https://doi.org/10.1007/s10533-014-9987-9

Yanosky, T.M., Hupp, C.R., Hackney, C.T. 1995. Chloride concentrations in growth rings of Taxodium distichum in a saltwater-intruded estuary. Ecological Applications 5 (3), 785-792. https://doi.org/10.2307/1941986

Yanosky, T.M., Vroblesky, D.A. 1992. Relation of nickel concentrations in tree rings to groundwater contamination. Water Resources Research 28 (8), 2077-2083. https://doi.org/10.1029/92WR00731 


\section{Supplementary material}

Al

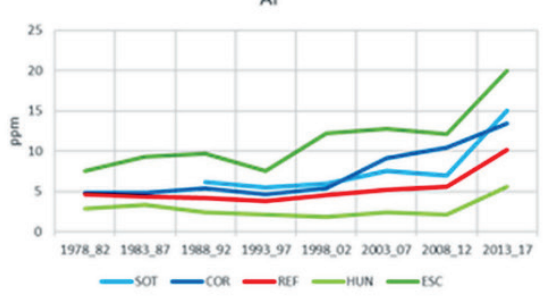

$\mathrm{Mn}$

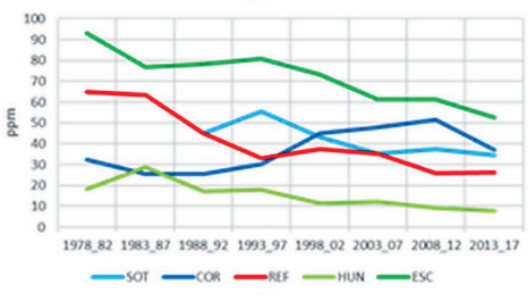

$\mathrm{Ni}$

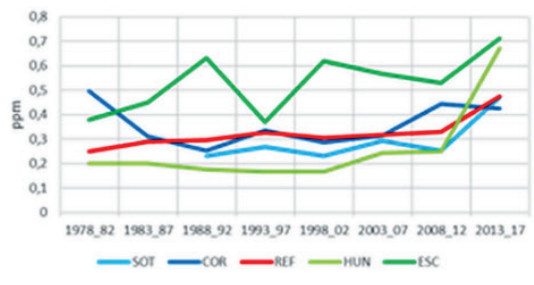

Mo

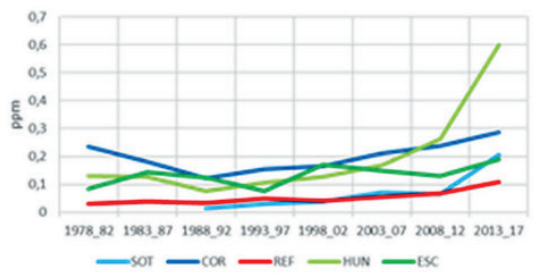

$\mathrm{Pb}$

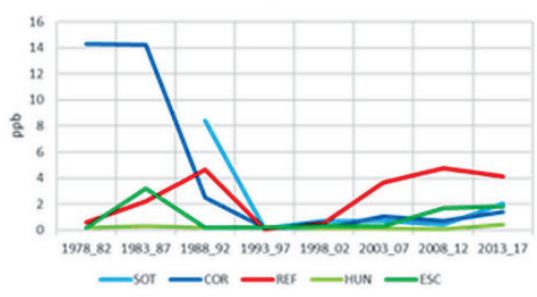

v

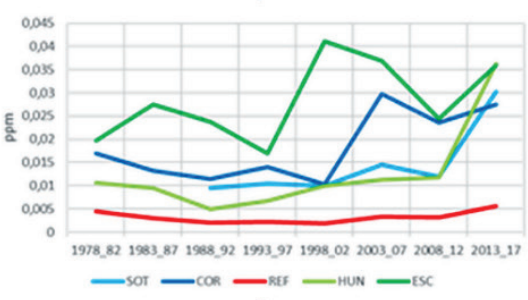

$\mathrm{Fe}$
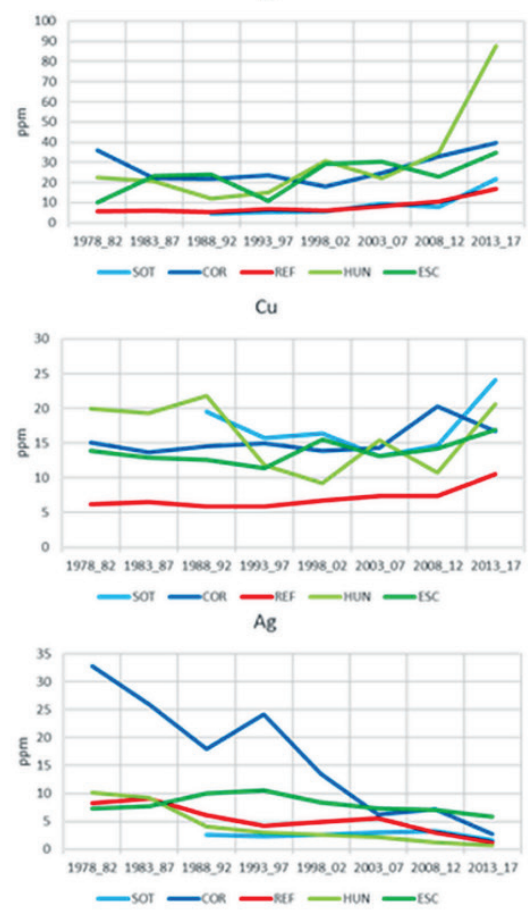

$\mathrm{Cr}$

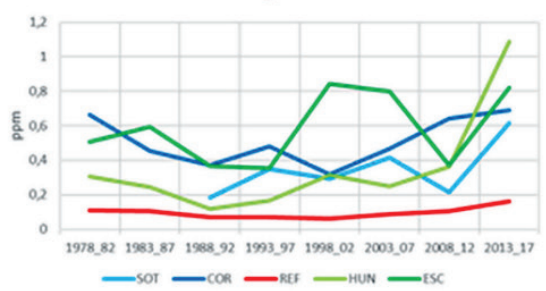

co

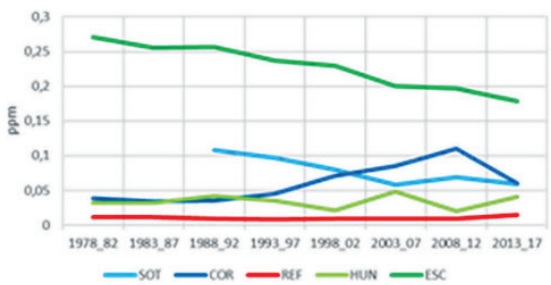

$\mathrm{Zn}$

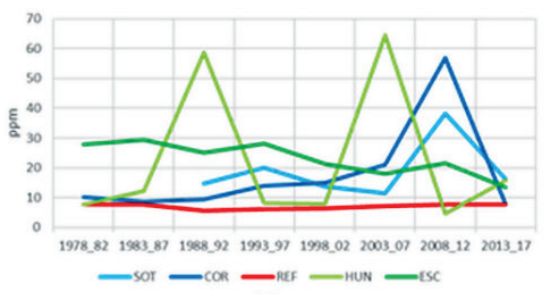

$\mathrm{Cd}$

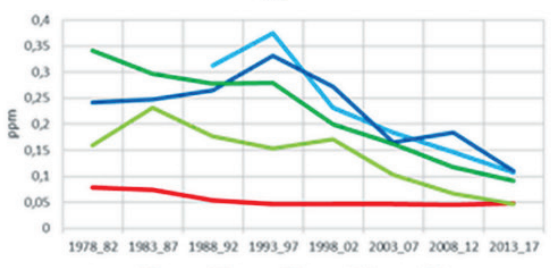

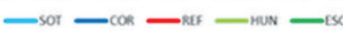

Figure S1. Temporal evolution of the average concentration of each element in the five sampling sites. 
Delapierre et al.
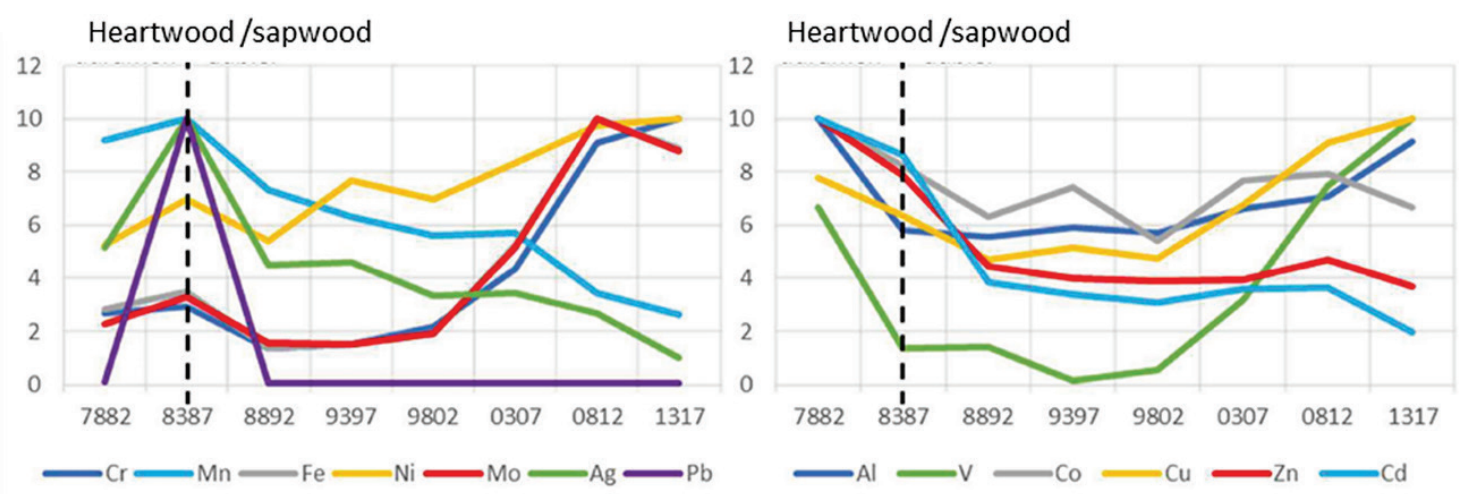

Figure S2. Example of changes in element concentration in the interface between hearwood and sapwood (Tree \# R3). In the left panel, peak in element concetrations can be seen in the border between sapwood/hearwood; while in the right pannel element concentrations tend to increase towards the pith from the sapwood / heartwood limit.

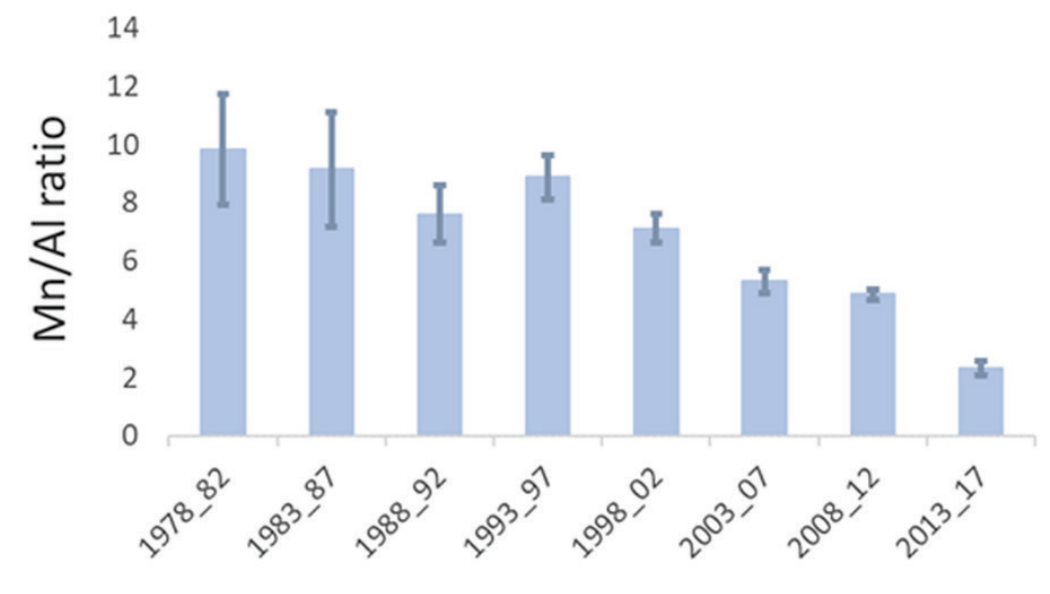

Figure S3. Temporal evolution of the Mn / Al ratio (averages of all sites) 